\title{
DECREPITUD, ESPLENDOR Y LABIA EN LA FUENTE DE LA EDAD
}

\section{José Enrique MARTÍNEZ FERNÁNDEZ}

\author{
Universidad de León
}

La fuente de la edad apareció en 1986. Su autor, Luis Mateo Díez, había publicado, dentro de la narrativa, un libro de cuentos, Memorial de hierbas (1973), dos novelas cortas, Apócrifo del clavel y la espina y Blasón de muérdago, publicadas las dos en 1977, un Relato de Babia (1981) en el que se indaga en la memoria de los orígenes (un territorio, unas costumbres, una tradición, unas gentes y sus maneras seculares de vivir) y la primera novela larga, Las estaciones provinciales (1982). Con esta última obra se iniciaba un proyecto ambicioso. Desembocaba su autor en la ciudad de provincias de los años 50 -la de la adolescencia del propio Luis Mateo- y construía un territorio literario en cuyo alzado colaboraron también grupalmente -aunque cada uno a su manera- José María Merino (El caldero de oro, 1981) y Juan Pedro Aparicio (El año del francés, 1986, y Retratos de ambigú, 1988). De todo ello di cuenta en mi libro La ciudad inventada (1994) y no voy a volver sobre el asunto. En el caso concreto de Luis Mateo Díez, Las estaciones provinciales fue la novela más pegada al terreno (se ha hablado de 'realismo'), pero con ella iniciaba la fundación de un mundo con señas de identidad propias, a la vez que daba cuenta de una especial inventiva para fantasear mundos posibles de singular originalidad que, centrados en lo cercano, aspiraran a lo universal. La fuente de la edad supuso un paso más: el mundo 'realista' de la novela anterior se deslizaba hacia la leyenda, el mito y el sueño; como el propio escritor dice, la novela trastoca la dimensión realista en una dimensión metafórica, pero sin escindirlas, mezclando ambas dimensiones (Díez, 1992: 101). El ciclo se cerraría con El expediente del náufrago (1992), novela en la que el espacio urbano aparece más diluido en favor de un ámbito cada vez más interiorizado. Las tres novelas forman una verdadera trilogía, la trilogía de la ciudad de provincias como espacio en el que los personajes viven experiencias que, sobre todo en La fuente de la edad, forman parte de la aspiración secular del hombre: la realización del sueño, del ideal, del mito de la eterna juventud.

La fuente de la edad consiguió el Premio de la Crítica y el Premio Nacional de Literatura a la mejor novela del año 1986. No era Luis Mateo Díez un escritor desconocido, pero novela y premios supusieron su consagración definitiva. A muchos de los que entonces leímos la novela nos pareció una obra que marcaba un hito en la narrativa española del momento. De hecho, tanto el autor como la novela colaboraron decididamente en la renovación que la novelística española inició en torno a 1975 y que puede resumirse en una frase del propio Luis Mateo: contar para encantar. Se trataba de huir de estériles experimentalismos y de volver al origen de la narración (oral o escrita): contar una historia que por sí misma subyugue al oyente o al lector. La fuente de la edad puede considerarse hoy como una obra clásica de nuestro tiempo; la edición en una colección de clásicos antiguos y modernos así lo corrobora1. La crítica se ha acercado a ella intentando desentrañar sus orígenes, el mundo novelado y su con-

\footnotetext{
${ }^{1}$ Díez, Luis Mateo, La fuente de la edad (ed. de S. Alonso), Madrid (Cátedra,col. "Letras Hispánicas”) 2002.
} 
formación literaria en diferentes estudios que empiezan a formar ya un bosque profuso e intrincado.

La 'historia' de La fuente de la edad ilustra el fracaso de los ideales humanos. El grupo de cofrades del padre Gerónides (trasunto literario de un mito local, Genarín) decide seguir las sendas y enseñanzas del ilustre presbítero don José María Lumajo en la búsqueda de la fuente de la edad, del venero de la eterna juventud. La presentación de los cofrades es repulsiva: Sariegos se animaliza en ameba o sabandija, Chamín está enfermo, don Florín luce su calva amoratada, Paco Bodes, un lobanillo embadurnado de ungüento, mientras Benuza deja caer, como un mosquito muerto, un pelo de la perilla.

El carácter circular de la novela exige que en el primer capítulo aparezcan los elementos que la cerrarán en las páginas finales: la azotea de Chon Orallo (otro cofrade), los enemigos del Casino, la inocente Dorina y la confirmación de que -como dirá Bodes- "todo es una metáfora".

Dividida en tres partes, la primera es la preparación de la búsqueda de la fuente. La acción transcurre en la ciudad. En cierto modo es una ciudad fantasmal, algo que se anuncia desde el momento en que los cofrades, al entrar en el Capudre, quedan como personajes de unas nuevas Luces de bohemia- transfigurados por el humo y los espejos. Fantasmal es Orestes Enebro, imaginado con los atributos que les faltan a los lisiados de la Peña, y fantasmal y pintoresca es la figura nocturna de Publio Andarraso. En Orestes Enebro surge también la aparición de lo grotesco, que proseguirá con la historia del mulo Celenque o con la de Olegario el Lentes y su mujer. La acción principal de esta primera parte consiste en el azaroso rescate del "Diario de la Omañona" del presbítero, verdadera guía de la fuente virtuosa. Cabe destacar que la acción transcurre de noche. La ciudad y sus calles parecen vacías. La vida vibra en los adentros, el drama reside en el interior, sea en el Capudre o en la buhardilla de Chon Orallo.

La segunda parte de la novela narra la expedición a la Omañona en busca del venero de la eterna juventud, de la Fuente, expedición de tono cervantino que origina el encuentro con personajes extraños, locos o visionarios como los propios cofrades: Elpidio Legaña, por ejemplo, o Manuela Mirandolina y el prodigio de la moza triscadora que, como la búsqueda de la Fuente, "es un sueño que confunde los sentidos" y que "alimenta el deseo de lo que a cada uno le queda de su juventud". De todos los cofrades, sólo Chon Orallo y Benuza, bajo el mito de la Fuente, vivirán una experiencia diferente, la del amor, experiencia que tuvo su momento único e irrepetible.

Cuando los cofrades descubren que todo lo referente al "Diario de la Omañona" es una burla de sus enemigos del Casino, se inicia la tercera parte, la de la venganza, de nuevo en el entorno urbano. Cumplida la venganza, la ilusión, al fin, ha caído por tierra. Los ideales no pueden sustentarse sobre la falsedad y todo ha sido una gran mentira: el "Diario", las Aguas Virtuosas, el boato de los socios del casino, la vida y hasta la muerte, fingida en el caso de Paco Bodes.

El regreso de los cofrades al santuario -la azotea de Chon Orallo- es el reencuentro con la realidad. La ciudad viste ahora de blanco; los personajes fantasmales de la noche (Publio Andarraso) reaparecen. El Caño Rucayo sigue manando como un eco 
del Mágico Venero: es, quizá la ilusión de que, pese a las burlas y convenciones, la imaginación, la quimera, el mito, siguen alimentando al hombre. Como un símbolo final, el cuerpo de Dorina que cae desde lo alto era "un copo vivo sobre aquella ciudad muerta".

La fuente de la edad es una novela circular que termina donde empezó, en la azotea de Chon Orallo, donde nacieron y murieron los sueños de los cofrades. Esta forma circular se organiza conforme a los tres actos del drama clásico (exposición, nudo y desenlace) y viene aderezada por una decidida 'voluntad de estilo', un humor que conjuga cervantismo y esperpentismo y una admirable variedad de registros lingüísticos que mezclan lo declamatorio y lo coloquial, lo vulgar y lo culto, lo sagrado y lo profano, lo alto y lo bajo, en un ejercicio paródico lleno, a la vez, de sabiduría y amenidad. La ceguera ante lo que La fuente de la edad tiene de parodia motivó la incomprensión de algunos lectores de primera hora.

No voy a incidir en aspectos sobre los que la crítica se ha detenido preferentemente, aunque pueda aludir a ellos: los orígenes ${ }^{2}$, la oralidad primigenia, el diálogo, el protagonista coral, el discurso narrativo, el humor, la base literaria de la parodia ${ }^{3}$, etc., etc. En este trabajo desarrollaré, en cambio, algunos otros motivos que, a mi parecer, son necesarios para una comprensión cabal de la novela: los signos de decrepitud urbana, frente al esplendor de la montaña y la literatización de la realidad pro parte de los cofrades que protagonizan la historia novelesca.

Iniciaré mi interpretación con un breve comentario de las primeras líneas de la novela 4 :

Bajo esa sombra primeriza del oscurecer, que parece una cortina granate en el relumbre de junio, Jacinto Sariegos se evade con el gesto solapado de la sabandija. Tiene la atmósfera un vago esplendor de flores cautivas, yerbas quemadas, alientos de pinar, ráfagas inocentes que expanden momentáneamente sobre la ciudad el aroma de la arboleda y de las vegas. Jacinto atesora en un instante ese aroma fluido que le libera de la salpicadura de los legajos, del polvoriento goteo de los expedientes, amordazados por los balduques en las destartaladas estanterías. Y avanza pegado a las aceras, vertiginoso sobre el desnudo riel de los bordillos, dispuesto a sobrevolar las esquinas con el fantasmal apresuramiento de quien está convencido de llegar tarde. Antes, por el túnel del Archivo, donde se respira el vaho cotidiano de las apolilladas singladuras administrativas y los siglos apilan sus contenciosas efemérides entre las ruinas de las pilastras consistoriales, la sabandija era una ameba, cuyos seudópodos rastreaban cansados $y$ ciegos el informe laberinto (13).

Estas líneas iniciales nos presentan un tiempo, un espacio, una atmósfera y un personaje. Está oscureciendo, lo que provoca una imagen brillante: "una cortina granate en el relumbre de junio". El tiempo de la acción va a ser, por lo tanto, la noche. En cambio, la parte central de la novela, que discurre por montañas y valles de la

\footnotetext{
${ }^{2}$ José María Merino (1992) tituló su introducción a una edición de La fuente de la edad "Fuentes de esta 'Fuente", que serían: la experiencia personal del novelista cifrada en la oralidad y las "cofradías" de jóvenes poetas y artistas de las que formó parte, el conocimiento de la ciudad de provincias y las filiaciones literarias (Cervantes, la picaresca, Pantagruel, ValleInclán, Kafka y Beckett) y cinematográficas.

${ }^{3}$ Del estudio que Santos Alonso (2002) dedicó a Luis Mateo Díez y su obra y, en especial, a La fuente de la edad, destaco la clarividencia interpretativa del "sistema mítico" sobre el que, paródicamente, sobrenada la novela de Luis Mateo Díez, y del "sistema esperpéntico y carnavalesco", derivado del magisterio valleinclanesco.

${ }^{4}$ En mis citas sigo la primera edición de La fuente de la edad, Madrid (Alfaguara) 1986. A sus páginas remiten las cifras que localizan cada cita de la obra.
} 
Omañona, se abrirá con una luminosidad esplendorosa: "La luz salpicaba las hojas del nogal gigante..." (113). En este y otros sentidos, esa parte central, titulada "La ruta de la fuente", que se desarrolla a lo largo de tres jornadas a la luz estival del día, actúa de contraste con las partes primera y última, en las cuales las acciones rastreras de los personajes -robo del baúl que contiene el "Diario de la Omañona" de don José María Lumajo y venganza contra los directivos y la sociedad del Casino, respectivamente- se realizan de noche. En cualquier caso, La fuente de la edad acoge los dos espacios típicos de la narrativa inicial de Luis Mateo: valles y montañas de su infancia y la ciudad provinciana de la adolescencia y primera juventud, todo ello sometido a un proceso de ficcionalización: 'la provincia inventada', pudiéramos decir, en cuya invención, memoria, imaginación y elaboración literaria cuajan en una metáfora universal de la condición humana.

Jacinto Sariegos, uno de los cofrades, avanza sigilosamente por las aceras de la ciudad, liberado de otro espacio cerrado: el Archivo en el que trabaja. La atmósfera urbana aparece decaída y triste: "flores cautivas", "yerbas quemadas"; lo que viene de fuera puede aliviar la opresión ("alientos lejanos de pinar"), pero son sólo ráfagas momentáneas de un espacio abierto: "el aroma de la arboleda y de las vegas", un "aroma fluido" que reaparece páginas después ${ }^{5}$ y que sirve de liberación de la atmósfera pobre y cerrada, ya no de la ciudad, sino del Archivo. Adjetivos como polvoriento, amordazados, destartaladas y apolilladas, y sustantivos como túnel y ruinas dan cuenta del "vaho cotidiano" en que se desenvuelve Sariegos: un ambiente cerrado y decrépito. Dos de esos adjetivos, polvoriento y destartalado, reaparecerán con frecuencia en la novela para ofrecer la imagen del deterioro 6 . Habrá "polvorientos desperdicios" en el corral al que se abre la cuadra en el que muere el mulo cautivo (47) y un "olor de la polvorienta cerrazón" en el viejo piso que cobija el baúl que contiene el apócrifo "Diario de la Omañona" (81); pero polvoriento es adjetivo que acompaña al ambiente cerrado del Archivo cuando éste reaparece al comenzar la tercera parte: allí los legajos "se derramaban como una masa polvorienta" (226) y el viento que logra colarse bate "las polvorientas resmas de los expedientes" (224); el sustantivo correspondiente acude en otra ocasión a relevar "el polvo milenario de los legajos" (29). Si polvoriento alude al tiempo secular, detenido e inmóvil en la atmósfera cerrada del Archivo, destartaladas añade un significado de deterioro y -como veremos- forma parte de los signos de decrepitud urbana que prodiga la novela.

Otra palabra que actúa como metáfora del Archivo nos interesa aún: laberinto; el Archivo es un "informe laberinto" que se reitera en otras páginas: "el laberinto del Archivo" (63); "...el laberinto del Archivo, donde las resmas y los anaqueles trenzaban los abigarrados espacios de aquella subterránea fosilización" (19); "los túneles del laberinto" $(20,23)$. Cuando hablamos de "laberinto" nos referimos a un lugar donde nos es difícil orientarnos y hallar la salida; lo laberíntico es complicado y confuso. Tales connotaciones hallamos aquí referidas al Archivo, acorde con esa atmósfera cerrada y decrépita a la que ya nos hemos asomado, muy diferente a otros signi-

\footnotetext{
5 "La brisa del oscurecer traía a la azotea la fresca humedad de las vegas" (15); "Según se adensaba el oscurecer la humedad de las vegas parecía hacerse más cercana. Ascendía el aliento del ejido con el frescor vegetal de los prados y las huertas" (21).

${ }^{6}$ Ricardo Senabre (1999) ha reducido los diferentes motivos de la narrativa de Luis Mateo Díez a un tema único con distintas modulaciones: "la concepción de la vida como degradación, como ruina, como algo condenado irremisiblemente a la extinción y el olvido".
} 
ficados simbólicos de larga tradición, profana o religiosa, y que Luis Mateo Díez aprovecha para referirse al espacio subterráneo que recorren las aguas virtuosas o al secreto -la fuente- al que accederán sólo quienes recorran la difícil senda sagrada de los iniciados7. El laberinto ofrece en la narrativa de Luis Mateo Díez, por otra parte, un simbolismo existencial en el que indagó Castro Díez (1999).

Nos resta tratar del personaje. "Jacinto Sariegos se evade con el gesto solapado de una sabandija". Un nombre que lo individualiza, una acción aprovechando las sombras del oscurecer y un símil que animaliza sus ademanes: 'sabandija'; como dicho reptil, Sariegos se fuga del laberinto del Archivo y camina apresurado ocultándose en las sombras. No olvidemos que 'sabandija' significa, además, 'persona despreciable' (DRAE). La animalización de las personas es uno de los rasgos esperpénticos más palpables, como la crítica ha subrayado, pero ningún personaje sufre tantas transformaciones animales como Jacinto Sariegos. En estas líneas iniciales, la ameba, con sus seudópodos "cansados y ciegos", que se mueve torpemente por un laberinto sin forma, confuso, se opone a la sabandija que huye intentando ocultarse; páginas adelante, Sariegos, esperando en el Archivo una llamada telefónica, consume tiempo "como una termita en su insaciable cobijo" (223). A lo largo de la novela, Sariegos será esa sabandija huidiza y medrosa que se diluye entre las sombras (72), una "sabandija mensajera" (17) que trae a los amigos cofrades la noticia de que los enemigos del Casino trabajan con la misma hipótesis que ellos sobre el "Diario de la Omañona" del presbítero; será la sabandija que percibe en sus estómago las ancas indigestas de las ranas (23) o que no puede apartar de sí una obsesión (34), que se desliza cautelosamente escaleras abajo (87) o que evoca el subterráneo del Archivo (29), donde hasta "el viento rastrero" se colaba "como una sabandija" (224). Pero el carácter cauteloso del que huye a escondidas en la noche transforma a Sariegos en murciélago, de actitud vigilante, o en "pájaro medroso" ("Frente al siete [...] se aposta Jacinto tras una carrera, parecida al sigiloso vuelo del murciélago...", 73; "De columna en columna vuela Jacinto como el pájaro medroso que, en la huida, elige siempre la rama menos apropiada", 73); sus idas y venidas en la fiesta nocturna del Casino evoca también la imagen del quiróptero ("Sariegos cruzó el salón con el leve aleteo del murciélago que vira entre las luminosas guirnaldas", 261; "Iba a posarse el murciélago tras su vuelo por los entorchados estucos", 262). No es extraño que el propio Sariegos se sienta murciélago ("Volando me veo por estos techos como un murciélago que acabase de fumar un faria", 258) o que tal mamífero volador aparezca en sus visiones ("El reclamo visionario atraía algunos revoloteos de fugaces murciélagos”, 273).

Este breve comentario de las primeras líneas de La fuente de la edad sirve, al menos, para ofrecer la posibilidad de llevar a cabo una "lectura transversal", siguiendo las diferentes líneas que cruzan toda la no vela, ofreciendo una dosis considerable de cohesión y coherencia, y que le sirven al lector de puntos de anclaje -de recuerdo y fijación- en su lectura.

\footnotetext{
${ }^{7}$ He aquí algunos ejemplos: "Quién fuera como aquella fuente, que en el fondo del laberinto vive con su risa de cristal..." (44); "El rumor del Caño depositaba en la noche esa voz de cristal nacida en el fondo del laberinto, que el eco parecía acrecentar, manando sin alma y sin edad en aquel hontanar del Rucayo" (45); "Un peregrino ambicioso no cejaría hasta enredarse en la mismísima senda sagrada del laberinto" (167); "El mapa y el monte, ya sabéis, son como la imagen y la realidad de un laberinto donde está el secreto" (208).
} 
Estos párrafos iniciales nos sitúan en la ciudad cerrada, a la que llega el aliento liberador de las vegas, del exterior, del espacio abierto. La ciudad es un espacio delimitado que acoge, a su vez, otros microespacios cerrados (bares, casas, buhardillas) o abiertos en el círculo urbano (calles, plazas...). Pero el novelista multiplica los signos de decrepitud y deterioro y de la atmósfera consecuente que exhala el abandono, lo cerrado, lo pobre, lo viejo. Baste un ejemplo, el de la casa donde se halla el baúl que rescatarán los cofrades: De la primera habitación salió un vaho de lanas y borras, un denso tufo de ropa apolillada (81).

Repasemos brevemente los materiales ruinosos del entorno urbano y sus microespacios. En el exterior, el barrio sobre cuya muralla cuelga la azotea de Chon Orallo es un "envejecido enjambre alrededor de la catedral" (15) y los tejados sobre los que se alza la azotea son "deformes en las abigarradas variaciones de hundimientos y colinas, oscurecidas las tejas por el humo de la antigüedad" (18); la zona del caserón donde Ovidio Orallo almacena los artilugios de su taller de bicicletas está amparada por "una cresta rojiza y destartalada" (19). El Archivo municipal, lugar de trabajo de Jacinto Sariegos, tiene, como hemos visto, "destartaladas estanterías", "apolilladas singladuras administrativas" sostenidas por "las ruinas de la pilastras consistoriales" (13); en sus bóvedas salen "húmedos desconchones" cuando llueve (29); las agujas del reloj marcan las horas sobre una "esfera descascarillada" y el teléfono suena como "averiada chicharra" (223); el tragaluz del Archivo es un "ojo maltrecho" con cristales rotos, "parcheados con cartón" (224). En estos interiores la decrepitud viene dada por el envejecimiento provocado por el tiempo, por el abandono y la incuria; así ocurre con el "fúnebre caserón" donde vive Chon Orallo, en cuya escalera una triste bombilla alumbra "la desnuda miseria"; a la buhardilla de Chon se accede por una "puerta desvencijada" (14). Otra buhardilla, la del pintor Feito, no es más que "una guarida enorme y destartalada" (33). La casona vieja que ampara el baúl con los escritos del clérigo don José María Lumajo consta de "dos pisos poco airosos, elevados como el enclenque cuerpo de una cigüeña enferma, sobre dos columnas de madera que desfallecen en sus pilastras"; del alero cuelga "el roto canalón como un harapo de hojalata" (73); el dúo de ancianos que duerme pacíficamente en una habitación de la casa, ajenos a todo lo que sucede en torno a ellos, ronca sobre "una destartalada cama matrimonial" (80), y del piso viejo sale "el olor de la polvorienta cerrazón" (81); tras cada puerta, un mismo panorama: "unos petrificados fantasmas que la mugre y la clausura habían convertido en volúmenes difíciles de delimitar, como si la metamorfosis del deterioro hubiese operado sin piedad sobre tantos objetos algún día cotidianos y reconocibles" (82). La escalera de la casa es de una "vieja y resquebrajada madera" (87), el baúl "era uno de esos objetos toscos y destartalados por su uso pasivo" (97), y lo que guarda en sus entrañas no son más que "volúmenes y volúmenes de pastas desconchadas y páginas invadidas por humedades y carcomas [...]. Un enjambre de maltrechas piezas coleccionadas en una decrépita colmena" (98). También el Capudre, donde se reúne y juega la Peña de los Lisiados, despide "enfermizas volutas" y la boca del bar es un "vientre ruinoso" (29). No es extraña a este paisaje urbano, bajo la inmovilidad de la noche, la imagen de la ciudadcamposanto que Jacinto Sariegos intuye en su deslizarse de sabandija entre las sombras nocturnas (72). El almacén del chamarilero Olegario el Lentes puede alzarse como símbolo de la decrepitud y el deterioro urbanos; la propia casa-almacén está sos- 
tenida por "la costra de unas vigas predestinadas al hundimiento"; el recinto lo envuelve "una atmósfera de oscura ruina"; todo ello es un bosque de "decrépita floresta" que acumula desordenadamente restos, desechos, residuos, la carcomida memoria de lo que fue (63). No menos simbólica es la agonía y muerte del mulo Celenque, grotescamente condenado a la cautividad por delito de guerra en una cuadra maloliente "tras una destartalada cerca de tablas" (48). La decrepitud del mulo condenado es quizá símbolo del tiempo, de la urbe y de la España cerrada del momento. Su "cuerpo derrumbado", "las cicatrices azules y moradas del cuerpo lacerado", su "vientre escuálido" su "cabeza desorejada"..., todo eran "señales de un cuerpo definitivamente desmoronado sobre sí mismo" (48).

El deterioro humano es, sin duda, el más penoso. Si ya en Las estaciones provinciales hay personajes que arrastran por la vida cojeras, manqueras y otras carencias físicas, en La fuente de la edad la Peña de los Lisiados compone la imagen -en boca de uno de ellos- de "la condición de lo incompleto, la condición de que aquello que nos falta es ya patrimonio de la muerte, preludio de ese porvenir fatal" (31). Los Lisiados han creado un personaje fantasmal, Orestes Enebro, reconstruido con los atributos que faltan al conjunto de los Lisiados. "Sería un espejo donde mirar nuestras carencias recreadas, una fantasía para aceptar y derrotar a la vez el recuerdo y la penuria" (31). Grotesco personaje fantasmal es Orestes Enebro, llegado de "un mal sueño", a quien el pintor Feito dio corporeidad al retratarlo en un lienzo, destruyendo así la fantasía y colocando ante la Peña el verdadero espejo de sus deformidades. Podemos dar un alcance mayor a las mermas físicas de los Lisiados, signos de un tiempo en que el mutilado, de guerra o no, era una presencia cotidiana: pueden representar, además, carencias de carácter existencial, acaso la poda de los ideales y su imposible realización.

Todo este ámbito de decrepitud es el que aparece en la primera parte de la novela. Contrasta con la magnificencia y el lujo del Casino de la ciudad en la tercera parte. En él se enfrentarán dos mundos contrarios: la alta sociedad y la de 'medio pelo', el boato y lo corriente y pobre. Baste como muestra del lujo esta breve descripción: En el gran salón de la Sociedad Recreativa del Casino las lámparas de araña multiplicaban la dorada pedrería en sus reflejos cristalinos, como si un incendio de luces amarillas fuese asolando los techos, derramando sus llamas como lenguas centelleantes que lamieran los arabescos estucados (248).

Fiestas, Juegos Florales, bailes, adornos...; pero el júbilo acabará en llanto y la fiesta en tragedia, con la venganza urdida por los cofrades, dando cuenta de la miseria humana que esconde el adorno: "Así es la Sociedad [...]. Fuegos de artificio encubriendo la carcoma y la náusea", comenta un personaje; y otro remacha: "Todo un símbolo del oropel y la ruina" (275). Al fin, el Casino se convirtió en "un desolado paisaje" que daba "la sensación de una secreta tormenta que había descargado en la oscuridad" (284).

Los dicterios contra la ciudad, que se habían ido sembrando en la primera parte ('ciudad impía', 'emputecida urbe', 'puta ciudad'), se acumulan en las páginas finales: 'Urbe emputecida', 'urbe maldita', 'urbe desolada', 'urbe de conejos y garduñas'. Es, de nuevo, la imagen de la ciudad-cementerio, que aparece ahora en la voz impostada de Paco Bodes: Liso cadáver de impenitente ruina-declamó Paco Bodes- nadie va a te- 
ner contigo la piedad de separar una punta del sudario para mirar tu rostro, ajado en los siglos que sellan el pergamino de tus piedras fundacionales. Yaces sin gloria entre la podredumbre de quienes te quisieron invicta. Mueres en la tribulación de aquellos pendencieros que te llamaron heroica (295).

La capa de nieve sobre la ciudad es el blanco sudario que la cubre, el 'lapidario mármol' de la 'ciudad muerta'. Un final común a la trilogía, pues en Las estaciones provinciales el blanco manto de la nieve diluye los perfiles y deja a la ciudad sepultada y abandonada a su suerte, resignada a su abandono, convertida en inhóspito recinto, mientras que en El expediente del náufrago el mar de la vida en que uno se desenvuelve es, finalmente, "un mar de nieve fácil de emparentar con el de los sueños de tantos extravíos y naufragios".

La ciudad y sus microespacios se metaforizan cuando quiere ofrecerse una expresión más plástica de los mismos. Así, uno de los antiguos barrios "apiñaba su mole como un envejecido enjambre alrededor de la catedral" (15); el humo del Capudre semeja "nieblas que cubren espesas las superficie de los lagos" (29); una cuesta cae "como un puñal vencido entre el dédalo de las callejas" (43); el almacén del chamarilero es un bosque en cuya espesura batallaron fieras y serpientes (cap. 4); las casas viejas se desparraman en la noche "como lóbregas matronas que el viento aplastó" (72); la ciudad nocturna, vacía, inmóvil, con sombras fantasmales que la recorren, con brillos de luna en las baldosas, evoca la imagen del camposanto, la ciudadcementerio (72-73), que en las páginas finales aparece cubierta por un sudario de nieve, mientras caen copos espesos "como una bandada de pájaros blancos", símil que se reitera, con variaciones, hasta cuatro veces: "espeso aleteo", "las alas de los blancos pájaros", "plumas imperturbables, mudas en su vuelo y en su caída" (297). La reiteración de una misma imagen nos dice que cuando el novelista halla el símil sugerente o la metáfora expresiva, propende a fijarlos en la memoria del lector; la imagen reiterada da cohesión, por otro lado, a una manera de contemplar literariamente el mundo.

Sobresalen las imágenes en que el plano evocado es un entorno marítimo ${ }^{8}$. El tejado de la azotea de Chon Orallo "era como el recortado puente de mando de un raro navío, anclado en aquel mar de agolpadas techumbres" (18); es una imagen que amplía lo evocado más adelante: “En el puente demando de la azotea la brisa contagiaba ese apacible rumor de un mar de junio, como si en el oleaje de los tejados se desprendiese un murmullo de peces, una salpicadura de escamas y briznas" (22); el oleaje de los tejados se recuerda después (24) en una visión que persiste intensificándose en cada reiteración. El blanco camisón de Dorina, que camina sobre una de esas olas el declive del tejado- "ondeaba en la brisa como la débil enseña del buque fantasma" (26), un buque fantasma que, sin duda, sirve de metáfora del viejo caserón. Es "el mar de la noche" que inunda la ciudad (28) -el oleaje nocturno (43)-, en el que los personajes, según las circunstancias, pueden sentirse "perdidos, cubiertos por la ola desorientadora" (77) o como náufragos que logran salvar sus pertenencias (97), que no son otras que el baúl con los escritos del clérigo Lumajo, baúl que, desamparado en el mar de la noche, semejaba "un objeto extraño que desde algún ignorado lugar

\footnotetext{
8 "Todo es una metáfora, dice Paco, señalando la noche y la ciudad que, desde la azotea de Chon, no son muy distintas al mar y al buque de la vida que lo navega" (Díez, 1998: 23).
} 
navegase a la deriva hasta una playa perdida" (109). Nada nos impide contemplar el mar de la noche ciudadana como ese mar existencial, de nuevo cuño, en el que resisten y sobreviven los náufragos de la vida.

La urbe nocturna de la primera y última partes de La fuente de la edad enmarcan la aventura diurna -a lo largo de tres días- de la segunda parte, en busca del sagrado venero en la Omañona, en la montaña, por trochas y vericuetos que los cofrades han de recorrer como iniciados en el camino de purificación hasta llegar al prodigio del agua milagrosa que devuelve la juventud. Frente a las aventuras nocturnas de los cofrades en la ciudad, la aventura en la montaña se inicia con la luz esplendente del día. Las descripciones de las diferentes paisajes de montaña que recorren o contemplan los cofrades acentúan el renacer diario, en contraste con lo viejo y decrépito de la ciudad, por más que haya pueblos sumidos en la soledad y casas abandonadas, como si lo humano estuviera amenazado de ruina frente a la permanente regeneración de la naturaleza. Por contraste con las sombras nocturnas de la urbe, aquí el espacio es abierto, luminoso y pacífico, de forma que dota de equilibrio vital, ajeno a las desmesuras urbanas, como el aire limpio es ajeno al vaho secular del Archivo o a las 'nieblas' del Capudre: Volaba un milano en lentos y sostenidos círculos, y rumoreaban los rebaños por los pastizales, entre el careo intermitente de los pastores. La quietud y el clamor de la mañana se fundían en la ampliada resonancia del valle, con un ritmo de silencios solemnes y lejanas algarabias, ecos perdidos que arrastraban voces, trinos, campanas (143).

Es difícil no evocar el locus amoenus o un cierto ambiente eglógico en relación con los pastores, por ejemplo, en su retorno al atardecer: Volvían a oírse, entre la contenida respiración vegetal del valle, los ecos de las voces que arreaban a los rebaños en el regreso, y las pacientes señales de las esquilas. Se doraba el horizonte... (211); con el regreso del campo se da entrada pacífica a la noche de la montaña: La noche no aventaba nada que no fuese quietud, ningún misterio parecía poseerla. Su respiración, entre el rumor escondido de los regueros en la vega y el frágil sueño de los pardales en el nogal, se esparcía como el pulso de un durmiente sereno y feliz (219).

En la montaña anida la sorpresa, el misterio, el prodigio, el mito (la Fons Aetatis) y la leyenda: las ondinas o cristalinas de los ríos, la culebra que mamó los pechos de la joven casada, el pelo que se torna blanco por un miedo pavoroso ante una alimaña, el caldero de oro o el tesoro escondido. Como dice Manuela Mirandolina, "el monte siempre tiene algo escondido [...]. Mil veces que subas y bajes, y siempre hay algo que no encuentras" (151). No encontraron los cofrades el venero virtuoso, pero permanecerá en ellos como un sueño.

La montaña deparó, además, el encuentro con visionarios que se cruzan en la aventura, enriqueciéndola o perturbándola. No hablo de los pastores generosos que ofrecen pan y lecho humilde, sino de "figuras" inesperadas, personajes extraños o locos que, según el aparecer de Santos Alonso (2002: 64) "simbolizan, por activa o por pasiva, las posibles escapadas de la realidad opresiva a través de la locura o la imaginación". Independientemente de la importancia que cada uno tenga en la trama novelesca, no puede olvidarse que en un relato de aventuras y de camino, como es la parte central de la novela, el encuentro con quienes ayudan o perturban la aventura es, además de procedimiento muy cervantino, algo consustancial al desarrollo de la historia. Es el caso de Pidio Legaña, de rara facha, pesado, terco, burlón, de enuncia- 
dos sucintos que compendian una sabiduría popular a ras de tierra; al perturbar el camino natural de la aventura da lugar a la experiencia amorosa irrepetible de Benuza y Chon Orallo bajo la sugestión del venero inagotable. Domingo, de cuerpo desmesurado y fofo, sueña con un noble abolengo y porta espada herrumbrosa para defenderse de la "bestia lúbrica" del gallo del corral. La vieja Manuela Mirandolina practica una filosofía sentenciosa que compendia verdades de andar por casa, cimentadas en la experiencia de la vida y de la edad. A ella deben Benuza y Paco Bodes la visión alucinada del prodigio de la moza triscadora, náyade, ninfa u ondina cuya aparición casi ritual es, ya citamos antes, "como un sueño que alimenta el deseo de lo que a cada uno le queda de su juventud", dando campo a la fantasía y al deseo frente a la chata realidad. Añadamos las figuras de Basilio Candemuela y su "enfriamiento pertinaz", la locura animalizada de Belisario Madruga en su Filosoferio y el imperativo, severo, exasperado, admonitorio y disparatado fray Priscilo, "el fraile tronado". Cada uno a su manera ha escapado de la realidad a través de la fantasía o la locura, contrapunto, al fin, de la locura fantasmagórica de los cofrades que persiguen una quimera imposible.

Otro capítulo diferente, que anuncié al principio del trabajo, es la literatización de la realidad por parte de los cofrades. No es preciso añadir que es otro rasgo típicamente esperpéntico de La fuente de la edad y procedimiento esencialmente paródico. "Todo es una metáfora" (28) dirá Paco Bodes, el cofrade que ejerce de bardo provincial. Bodes tiene una visión metafórica del mundo. Pero no es una visión necesaria la suya, no suplanta a nada, simplemente lo dobla. La metáfora es en Paco Bodes la reiteración de lo ya dicho. La metáfora es, en su voz, una parodia de la realidad. Ante las ancas de rana que crepitan en la cazuela buscará el doblete metafórico: "Una metáfora aproximada [...] podría ser: pálidos muslos de verdes ninfas en el bullicio del pimentón" (17). Pero quizá sean la cita y la declamación los rasgos más llamativos, que acentúan hiperbólicamente el tono paródico de la novela.

Las citas apoyan el discurso de los cofrades, pero en un tono enfático que pone en solfa la cita misma9 ${ }^{9}$ La cita introduce en el propio discurso la voz ajena. Entre los cofrades, la cita viene a subrayar una idea o a dar empaque a la frase propia. Pero en la boca de Benuza o en la de Paco Bodes, que recurren de continuo a la voz ajena, se mezcla todo tipo de citas: cultas y populares, de escritores locales o universales; lo alto y lo bajo, lo apócrifo y lo verdadero se igualan en un todo falsamente culto, es decir, declamatorio y pedante: paródico.

La facundia de Benuza -"te pierde la labia”, le dice Chon Orallo (18)- trae a su boca múltiples citas, de Juan Ruiz ("yantar y ayuntarse, según la preclara lírica del Arcipreste", 15) a cualquier pelanas ("Como dijo Celerio Alpino a la puerta del bosque te aguarda el sueño", 198). Por el medio, citas más o menos chuscas ("sed locuaces, capaces y pertinaces, decía don Antonio Garrotín...", 34), más o menos pertinentes de Publio Capistrano (44), Criselio (Cenobio etrusco) (165), el eremita Barrientos (172), Nicéforo (183), Roldán Benares (192) o Sem Baruk (238), nombres supuestos

\footnotetext{
${ }^{9}$ Dejaré a un lado la parodia que se ejerce sobre determinadas figuras mitológicas a través de las cuales se quiere interpretar, acaso interesadamente, la realidad. Tampoco aludiré a las referencias a obras y escritores locales como el Chato de Cirujedo, autor de la novela El Lobo del Desván y otras obras (31,233), Ulpiano Curueño, cuyos versos didascálicos celebraban la historia patria (24) o el propio Paco Bodes, poeta reconocido, al que premian con Flor Natural en el Casino, premio en torno al cual se urde la venganza contra aquella Sociedad Recreativa.
} 
para distintas ocurrencias que quieren ser la muestra externa del barniz erudito de los cofrades, capaces, si es preciso, de acudir a la cita latina: "Saepe levi somnum inire susurro -citó Benuza, entrecerrando los ojos y sorbiendo el aroma de las húmedas florestas" (144); el mismo personaje declamará afectadamente alguna otra cita latina agradeciendo un demorado reposo en el atardecer de la montaña (153). Ante tal afluencia de voces ajenas, Chon Orallo le dirá a Benuza, que usa la cita como argumento persuasivo: "No me andes con citas" (238). Lo dicho puede aplicarse también al bardo provincial Paco Bodes, que alude, cita y declama versos propios y ajenos, de vates locales como él mismo. No es extraño que, en una ocasión, Bodes y Benuza alternen el recitado de versos que atribuyen a la lusitana Bernarda Ferreira de la Cerda (168). No falta en Bodes la presencia becqueriana ("La vida es un erial", 35), al igual que sorprendemos en boca de Sariegos alusiones rubendarianas degradadas ("la almorrana municipal y espesa", 262) o benaventinas ("alegre y confiada está la Sociedad", 264).

Son Bodes y, sobre todo, Benuza, los que afectan ademanes y discursos de una retórica engreída. Pero unos y otros cofrades -o los próximos a ellos- caen en la frase brillante. Les pierde la labia, en efecto; también la pose. Sorprendemos, por ejemplo, a Ovidio Orallo interpretando su papel de cocinero ("Alzó la mano con el cucharón de madera a modo de enseña") y declamando como un actor: "Ave, Jacintín, ya los batracios anuros crepitan y borbollonea la cazuela" (14).

"La labia no es patrimonio de los bardos", apostilló Sariegos ante las expresivas palabras de una dama del Casino: "Hablas como el poeta premiado". El bardo premiado era Paco Bodes, pero el verdadero actor era Ángel Benuza, que a su peculiar retórica envanecida añade un tono infatuado, propio de quien representa, de quien más que conversar, se escucha, declama. Me ciño a un pasaje de gran interés en el que Benuza "acentuando el tono declamatorio" lanza a los cofrades una verdadera pieza oratoria: "Estos tiempos emputecidos que nos tocó vivir son hijos de la ignominia y del desastre [...]. Ya veis quiénes los gobiernan: las peores varas, las más hipócritas, los zascandiles y las sotanas. La vida se va reduciendo al crespón y a la vergüenza. De la inteligencia han hecho un vertedero. Yo me pregunto cómo podremos sobrellevarlos, quién tiene la receta para, al menos, hacerlos pasaderos, disimulando su terquedad y oprobio" (44-45). Ante los ojos de Sariegos se dibuja "la imagen del orador" transformada "en una estatua de piedra marmórea" al amparo de la hornacina del Caño Rucayo, bajo la cual se destacaban Paco Bodes y el propio Ángel Benuza como "dos actores en el centro del escenario" (45).

El tono declamatorio acompaña a los cofrades hasta el final, cuando, tras la venganza del Casino, regresan en la noche nevada alternando sus invectivas contra la ciudad: "Ahora pisamos tu entraña, urbe maldita...", inició Sariegos; "También tu corazón pisamos -le secundó Ángel Benuza..."; "Liso cadáver de impenitente ruina declamó Paco Bodes..." (295). Retórica, énfasis, pedantería, parodia. Les perdía la labia.

Esta indagación parcial en un par de aspectos de La fuente de la edad muestra la riqueza de una obra clásica de nuestro tiempo que expresa algo de lo que somos y aquello a lo que aspiramos: el sueño o el mito de la vida en plenitud, liberada del acoso del tiempo, de la decrepitud y hasta de la muerte, un ideal imposible, abocado 
al fracaso. No permanecerá el sueño en su integridad, pero sí, al menos, como dice un personaje, la piel de un sueño, el recuerdo de la piel de un sueño, la vaga evocación del deseo inalcanzable. Al fin, la fuente virtuosa no es más que otra metáfora, una metáfora de las aspiraciones del hombre, una metáfora del alma o de la vida.

\section{Referencias bibliográficas}

Alonso, Santos. 2002. "Introducción” a su ed. de La fuente de la edad, Madrid (Cátedra), pp.9-76.

Castro Díez, Asunción. 1999. “Territorios imaginarios de Luis Mateo Díez. La configuración del laberinto como símbolo de la vida", La Página, 36, 4.

Díez, Luis Mateo. 1992. El porvenir de la ficción, Madrid (Caballo Griego para la Poesía)

Díez, Luis Mateos. 1998. La línea del espejo (Un relato de personajes), Madrid (Alfaguara).

Merino, José María. 1992. "Fuentes de esta 'Fuente'", prólogo a La fuente de la edad, Madrid (Espasa-Calpe)(Austral), pp.1-9.

Senabre, Ricardo. 1999. “Temas y motivos en la narrativa de Luis Mateo Díez”, en Irene Andrés-Suárez, Inés D'Ors, y Ana Casas, (eds.), Luis Mateo Díez (Grand Séminaire de Neuchâtel, 26-28 de octubre de 1999), Neuchâtel (Université) pp.3544. 